\title{
RENOVATION OF A BUILDING AND ITS IMPACT ON AIR POLLUTION
}

\author{
P. KAPALO ${ }^{1}$, C. BACOTIU ${ }^{2}$, F. DOMNITA ${ }^{3}$, Martina ZELENAKOVA ${ }^{4}$
}

\begin{abstract}
Renovation of a building and its impact on air pollution. The main purpose of the research presented in this paper is to quantify the amount of carbon dioxide produced by a standard house with four occupants before and after rehabilitation measures. As expected, these retrofitting actions had a positive effect on energy consumption and, in consequence, the $\mathrm{CO}_{2}$ emissions decreased significantly. After applying thermal insulation, $\mathrm{CO}_{2}$ production values derived from heating of the building were reduced by $68 \%$. The replacement of electrical household appliances decreased $\mathrm{CO}_{2}$ emissions by $53 \%$. Also, based on experimental measurements we calculated $\mathrm{CO}_{2}$ production due to human breathing, for different types of activity. Subsequently, the yearly quantity of $\mathrm{CO}_{2}$ produced by breathing by a standard fourmember family was calculated. Finally, we estimated the contribution of human breathing to the total household $\mathrm{CO}_{2}$ production.
\end{abstract}

Keywords: building renovation, indoor air quality, carbon dioxide.

\section{INTRODUCTION}

Carbon dioxide $\left(\mathrm{CO}_{2}\right)$ concentration in the environment is constantly changing, mainly because of human activity impact and is different in specific regions of the world. Every year, scientists find increasingly levels of $\mathrm{CO}_{2}$ concentration in the atmosphere as a result of human activities and natural processes. According to the measurements done by the atmospheric observatory at the National Oceanic and Atmospheric Administration (NOAA) at Mauna Loa, Hawaii, $\mathrm{CO}_{2}$ concentrations are now situated above 400 ppm (NOAA, 2017). In comparison, from early scientific research (Etheridge, 1998) conducted in Antarctica and Greenland, climatic data showed that around the year 1,000, the $\mathrm{CO}_{2}$ concentration was only about $280 \mathrm{ppm}$. The reason why the $\mathrm{CO}_{2}$ concentration in the atmosphere had begun to rise sharply is the Industrial Revolution. As the reported value for December 2016 is 404.48 ppm (NOAA, 2017), we can conclude that the concentration of $\mathrm{CO}_{2}$ in the atmosphere has increased by $44.45 \%$.

1 Technical University of Kosice, Faculty of Civil Engineering, 04200 Kosice, Slovakia, e-mail: peter.kapalo@tuke.sk

2 Technical University of Cluj-Napoca, Building Services Faculty, 400604 Cluj-Napoca, Romania, e-mail: ciprian.bacotiu@insta.utcluj.ro

3 Technical University of Cluj-Napoca, Building Services Faculty, 400604 Cluj-Napoca, Romania, e-mail: florin.domnita@insta.utcluj.ro

4 Technical University of Kosice, Faculty of Civil Engineering, 04200 Kosice, Slovakia, e-mail: martina.zelenakova@tuke.sk 
The most important producers of pollutants are the industry, the transport systems and the buildings. So, human activities affect the natural processes all over the world and, as a result, we have a constant increase of $\mathrm{CO}_{2}$ concentration in Earth's atmosphere.

The emissions produced by traffic are clearly reducing air quality in densely populated areas. The transport depends on the local flow of people and cars. In the automotive industry there is a great effort to build engines with the lowest production of harmful emissions. According to a research (Theurer 1999), it is possible to reduce emissions by optimizing the layout of the city buildings and by creating a suitable system of roads. These structural modifications have to reduce the concentration of pollutants almost in the same order of magnitude as the measures concerning the number of vehicles and vehicle fleet composition.

In villages and towns, if we leave aside the industry and transport impact, the largest amount of $\mathrm{CO}_{2}$ is released especially during the cold season, due to energy consumption for heating the buildings.

The buildings have direct consequences on the environment, beginning with the use of raw materials for their structure and ending with their operating mode, where the consumption of natural resources (water and fossil fuels) is leading to harmful emissions. For example, the Polish buildings have the highest average energy consumption for heating (63\% of their buildings are above the European average), while French and Polish buildings have the highest production of air emissions (Balart, 2005).

Serious efforts were made to construct buildings using efficient insulating materials, with thermal conductivity values less than $0.04 \mathrm{~W} / \mathrm{mK}$. The evaluation of these materials, in terms of life cycle building energy use, is the subject of several studies (Papadopoulos, 2007).

As previously mentioned, both the building shape and their arrangement in the urban environment can impact on air pollution around buildings (Xie, 2005). These specific measures can contribute to the improvement of air quality in a certain location, but they do not affect the overall worsening conditions of the Earth's atmosphere.

The $\mathrm{CO}_{2}$ concentration in different cities may vary. For example, in the city of Kosice in Slovakia, measured $\mathrm{CO}_{2}$ concentrations are fluctuating between $380 \mathrm{ppm}$ and $550 \mathrm{ppm}$.

Inside a building, in terms of indoor air quality, major polluters are people, because they produce more pollutants than any other source. A person may perform more or less intense physical activity, but still produces pollutants by breathing and sweating, which are natural metabolic processes. Although the percentage of $\mathrm{CO}_{2}$ in the air is approximately $0.03 \%$, for air quality assessment, $\mathrm{CO}_{2}$ is considered to be the most important component, due to its harmful effects.

This article focuses mainly on the possibility of reducing noxious emissions produced by everyday family life. The aim is to quantify the reduction of energy consumption for a standard household. 


\section{INCREASING THE ENERGY PERFORMANCE OF BUILDINGS}

As a reference building we chose a typical family house, having a standard thermal performance with respect to the majority of buildings that were made during the years of largest construction boom after Second World War in Slovakia. We assume that we have four inhabitants in this family house.

The assessed building was built in 1958 and has only one floor. The house has one living room, one kids room, one bedroom, one kitchen, one toilet and one bathroom. The total floor area of the house is $98.66 \mathrm{~m}^{2}$. The walls are made of brick and have two types of thickness: $600 \mathrm{~mm}$ and $350 \mathrm{~mm}$. The exposed walls area is $147.62 \mathrm{~m}^{2}$. The ceiling $\left(140.27 \mathrm{~m}^{2}\right)$ is made of wood, having on top a dry clay layer. The tiled roof is not insulated. The floor $\left(140.27 \mathrm{~m}^{2}\right)$ consists of wooden boards, laid on sand and slag, directly on the ground. Each individual room has double glazed wooden windows. The door of the house is also made of wood. The total exposed area of windows and door is $18.11 \mathrm{~m}^{2}$. Calculated energy requirement for heating was $33.707 \mathrm{kWh} /$ year.

Then, the house went through a rehabilitation process. The building envelope was insulated with mineral wool thermal insulation $(150 \mathrm{~mm}$ in thickness). The old windows were replaced with triple glazed wood-aluminium new windows. The ceiling was insulated with $150 \mathrm{~mm}$ XPS hardened polystyrene. The floor was insulated with $80 \mathrm{~mm}$ XPS hardened polystyrene. Now, the calculated heat energy demand is only 12,705 kWh/year.

Another option to reduce emissions in a family house (heavily promoted in society) is the replacement of old electrical equipment. In Table 1 (Carbon Footprint, 2016) we documented the annual electricity consumption for older and newer electrical appliances used in our standard home.

Table 1. Electricity consumption of appliances used in the home (Carbon Footprint, 2016)

\begin{tabular}{|l|c|c|}
\hline & $\begin{array}{c}\text { The annual energy consumption } \\
\text { for older domestic appliances } \\
\text { (kWh/year) }\end{array}$ & $\begin{array}{c}\text { The annual energy consumption } \\
\text { for new domestic appliances } \\
\text { (kWh/year) }\end{array}$ \\
\hline Electronics & 918 & 276 \\
\hline Cooking & 578 & 347 \\
\hline Lighting & 544 & 136 \\
\hline Refrigeration & 340 & 170 \\
\hline Washing machine & 272 & 190 \\
\hline Hygiene & 238 & 170 \\
\hline Air conditioning & 170 & 170 \\
\hline Ironing & 170 & 170 \\
\hline Other & 170 & 170 \\
\hline
\end{tabular}

The replacement of electrical equipment in our household generated an important reduction of energy comsumption, from 3,400 kWh/year to 1,731 
$\mathrm{kWh} /$ year. For a better visual comparison of the effects of the measures in place, we calculated the carbon footprint (Carbon Footprint, 2016).

Before construction renewal, $7.3 \mathrm{t}$ /year of $\mathrm{CO}_{2}$ were produced from heating the building and 1.7 t/year from electric energy consumed by (old) household appliances. In comparison, family $\mathrm{CO}_{2}$ production from transport by car is 2.1 $\mathrm{t} /$ year, and from transport by train and bus is $0.95 \mathrm{t} /$ year.

After construction retrofitting and after replacing household appliances, only $2.5 \mathrm{t} /$ year of $\mathrm{CO}_{2}$ were produced from heating the building and $0.8 \mathrm{t} /$ year from energy consumed by (new) household appliances. $\mathrm{CO}_{2}$ production values calculated for transport remained unchanged.

An unavoidable source of indoor $\mathrm{CO}_{2}$ pollution is human breathing. In order to obtain the $\mathrm{CO}_{2}$ mass flow produced by breathing, experimental measurements have been carried out in our house with four-member family. We measured the $\mathrm{CO}_{2}$ concentration, the indoor air temperature and relative humidity. From the measured values of $\mathrm{CO}_{2}$ concentration, we calculated $\mathrm{CO}_{2}$ mass flow rate, produced for different activities: sleeping, sedentary work, light physical work - using the method presented by Kapalo, (2014). $\mathrm{CO}_{2}$ mass flow rate produced from one person's breathing is: for sleep $7 \mathrm{mg} / \mathrm{s}$, for sedentary activity $11 \mathrm{mg} / \mathrm{s}$, for light physical work $32 \mathrm{mg} / \mathrm{s}$. The total production of $\mathrm{CO}_{2}$ from breathing for a fourmember family is estimated at $1.78 \mathrm{t} /$ year.

\section{RESULTS}

One of the goals of this research is the evaluation of $\mathrm{CO}_{2}$ released into atmosphere from our standard house with four residents. Table 2 presents the calculation results from which we can observe different $\mathrm{CO}_{2}$ production ratios, before and after the actions taken in order to reduce the $\mathrm{CO}_{2}$ production.

Table 2. Comparing the production of $\mathrm{CO}_{2}$ before and after measures

\begin{tabular}{|c|c|c|c|c|c|}
\hline & $\begin{array}{c}\text { Energy } \\
\text { consumption } \\
\text { before } \\
\text { rehabilitation } \\
\text { measures } \\
\text { (kWh/year) }\end{array}$ & $\begin{array}{c}\text { Production of } \\
\mathrm{CO}_{2} \text { before } \\
\text { rehabilitation } \\
\text { measures } \\
\text { (T/year) }\end{array}$ & $\begin{array}{c}\text { Energy } \\
\text { consumption } \\
\text { after } \\
\text { rehabilitation } \\
\text { measures } \\
(\mathrm{kWh} / \text { year) }\end{array}$ & $\begin{array}{l}\text { Production of } \\
\mathrm{CO}_{2} \text { after } \\
\text { rehabilitation } \\
\text { measures } \\
\text { (T/year) }\end{array}$ & $\begin{array}{c}\text { Reducing } \\
\text { the } \\
\text { production } \\
\text { of } \mathrm{CO}_{2} \\
\text { (T/year) }\end{array}$ \\
\hline $\begin{array}{l}\text { Heat loss in the } \\
\text { building }\end{array}$ & 31,592 & 6.3 & 10,265 & 2.0 & 4.3 \\
\hline $\begin{array}{l}\text { Heating of } \\
\text { ventilation air }\end{array}$ & 5,115 & 1.0 & 2,440 & 0.5 & 0.5 \\
\hline Heating total & 36,707 & 7.3 & 12,705 & 2.5 & 4.8 \\
\hline $\begin{array}{l}\text { Electrical } \\
\text { appliances }\end{array}$ & 3,400 & 1.7 & 1,731 & 0.8 & 0.9 \\
\hline Breathing (family) & - & 1.8 & - & 1.8 & 0.0 \\
\hline Transport in town & - & 2.2 & - & 1.1 & 1.1 \\
\hline Total production & 40,107 & 13.0 & 14,436 & 6.2 & 6.8 \\
\hline
\end{tabular}


From the results shown in Table 2, it can be seen that the largest contribution to $\mathrm{CO}_{2}$ production (four-member family living in a standard house) is made by heating. After applying thermal insulation, $\mathrm{CO}_{2}$ production values for compensating heat losses in the building were reduced by $68 \%$. Sealing the building (new thermal insulation and windows replacement) significantly reduces outdoor air infiltration rate and therefore will generate a $50 \%$ reduction in $\mathrm{CO}_{2}$ production corresponding to the heating of the ventilation air. The replacement of electrical household appliances reduces $\mathrm{CO}_{2}$ emissions by $53 \%$. People's breathing remains unchanged. Targeted arrangement of streets in the city and economical use of vehicles is expected to cut $\mathrm{CO}_{2}$ emissions by $50 \%$. Globally, taking into account all the $\mathrm{CO}_{2}$ emitters, after rehabilitation measures, the $\mathrm{CO}_{2}$ production rate decreases by $52 \%$. In Figure 1 we can observe the total $\mathrm{CO}_{2}$ production before and after the taken measures.

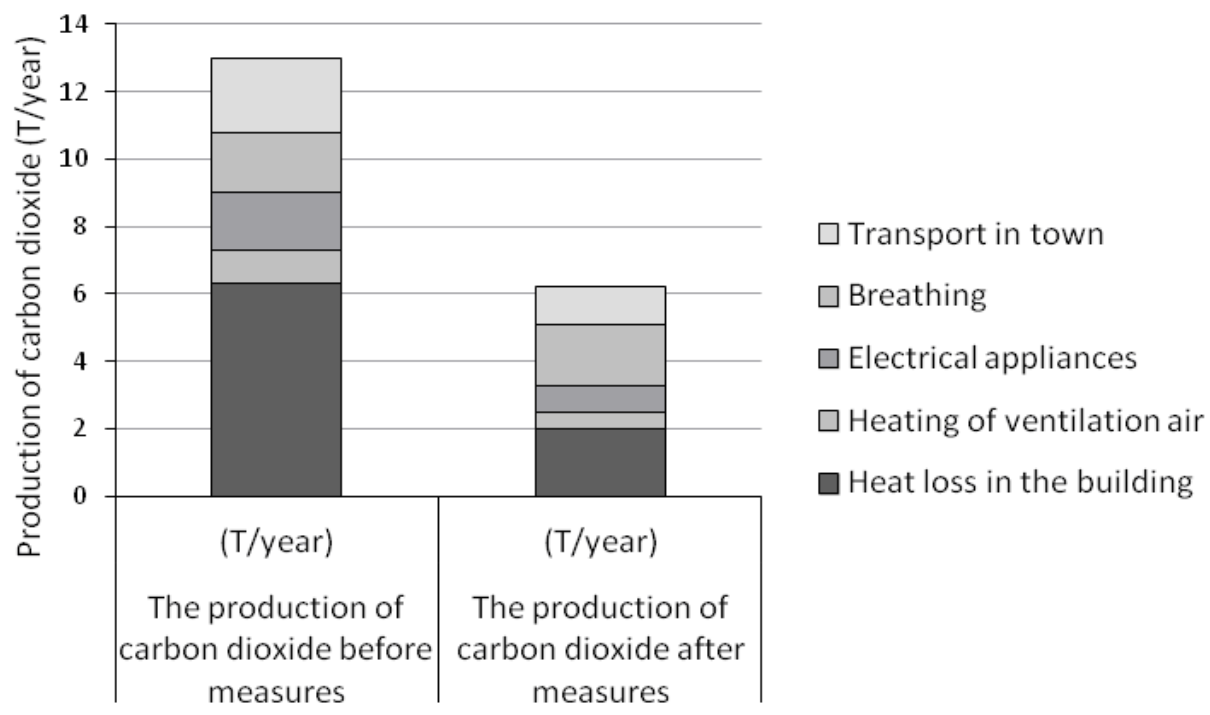

Fig. 1. Comparing the production of $\mathrm{CO}_{2}$ before and after measures

Before any measures, the four-member family $\mathrm{CO}_{2}$ breathing contribution was about $14 \%$ of the total production of $\mathrm{CO}_{2}$. After the implementation of all the measures, the proportion of $\mathrm{CO}_{2}$ production caused by breathing (which is unchanged in absolute figures) is now $29 \%$.

\section{CONCLUSIONS}

This paper examines the effect of house rehabilitation actions in order to reduce energy consumption and subsequently, to decrease $\mathrm{CO}_{2}$ production.

Also, from experimental measurements carried out in a four-member household we calculated human $\mathrm{CO}_{2}$ production for the following activities: sleep 
$7 \mathrm{mg} / \mathrm{s}$, sedentary activity $11 \mathrm{mg} / \mathrm{s}$, light physical work $32 \mathrm{mg} / \mathrm{s}$ - all for one person. Subsequently, we calculated the total quantity of $\mathrm{CO}_{2}$ produced by breathing by a four-member family: roughly $1.78 \mathrm{t} /$ year.

Out of the total $13 \mathrm{t} /$ year $\mathrm{CO}_{2}$ production for a non-insulated house with older electrical appliances, breathing contribution is $14 \%$. When the house was insulated, windows and doors were replaced and new energy-efficient electrical appliances were adopted, the total output of $\mathrm{CO}_{2}$ decreased to $6.2 \mathrm{t} /$ year and the contribution of breathing became $29 \%$.

Acknowledgments. This article was elaborated within the framework of the project VEGA 1/0307/16.

\section{REFERENCES}

1. Balaras C.A., Droutsa K., Dascalaki E., Kontoyiannidis S. 2005. Heating energy consumption and resulting environmental impact of European apartment buildings. Energy and Buildings. ISSN: 0378-7788. Volume 37, Issue 5, May 2005, Pages 429-442

2. Carbon Footprint Ltd, carbon footprint calculator for individuals and households. Worting House, Church Lane, Basingstoke, Hampshire, RG23 8PX, UK carbon footprint calculator for individuals and households, http://www.carbonfootprint.com/calculator.aspx

3. Etheridge D.M., Steele L.P., Langenfelds R.L., Francey R.J., Barnola J.M. and Morgan V.I.. 1998. Historical CO2 records from the Law Dome DE08, DE08-2, and DSS ice cores. In Trends: A Compendium of Data on Global Change. Carbon Dioxide Information Analysis Center, Oak Ridge National Laboratory, U.S. Department of Energy, Oak Ridge, Tenn., U.S.A, (http://www.esrl.noaa.gov/gmd/ccgg/faq_cat-3.html)

4. Kapalo P, Domnita F., Lojkovics J. 2014. Methodology for calculating the fresh air ventilation airflow rate based on $\mathrm{CO}_{2}$ concentration. Pollack Periodica, vol. 9 (2), Pages 89-97;

5. National Oceanic and Atmospheric Administration (NOAA) at Mauna Loa in Hawaii. 2017. http://www.esrl.noaa.gov/gmd/ccgg/

6. Papadopulos A.M., Giama E.. 2007. Environmental performance evaluation of thermal insulation materials and its impact on the building. Building and Environment. ISSN: 0360-1323. Volume 42, Issue 5, May 2007, Pages 2178-2187

7. Theurer W. 1999. Typical building arrangements for urban air pollution modelling. Atmospheric Environment. ISSN: 1352-2310. Volume 33, Issues 24 25, October 1999, Pages 4057-4066

8. Voznyak O., Sukholova I., Myroniuk K.. 2015. Research of device for air distribution with swirl and spread air jets at variable mode. Eastern European Journal of Enterprise Technologies, ISSN 1729-3774. 6 (7), Pages 15-23.

9. Xie X., Huang Z., Wang J.S.. 2005. Impact of building configuration on air quality in street canyon. Atmospheric Environment. ISSN: 1352-2310. Volume 39, Issue 25 , august 2005, Pages 4519-4530. 